\title{
PENGARUH NILAI JUAL OBJEK PAJAK, LUAS KEPEMILIKAN TANAH, DAN HARGA PASAR TANAH TERHADAP NILAI GANTI RUGI TANAH PADA PELAKSANAAN PEMBANGUNAN MANADO OUTER RING ROAD III
}

\author{
Hesty Mansyur \\ Bobby Jhon Vian Polii \\ Charles Reijaaldo Ngangi
}

\begin{tabular}{ll}
\hline Naskah diterima melalui Website Jurnal Ilmiah agrisosioekonomi@unsrat.ac.id & : Jumat, 27 September 2019 \\
Disetujuiditerbitkan & : Kamis, 17 Oktober 2019 \\
\hline
\end{tabular}

\section{ABSTRACT}

This study aims to 1) Analyze the effect of individually of the sale value of the tax object, land ownership area, and land market price on the value of land compensation in land acquisition development Manado outer Ring Road III (MORR III). 2) Analyze the effect jointly between the sale value of tax objects, land ownership area, and land market price on the value of land compensation in the procurement of land for the construction of MORR III. This research was conducted at the construction site (MORR III) from Fe bruary to October 2019. This research used quantitative descriptive methods. The data collected was primary data and secondary data. Primary data were obtained directly through interviews with key informants namely the Land Procurement Committee for Implementation of MORR III. Secondary data were obtained from the North Sulawesi Land Agency and the Central Statistics Agency. Secondary data is related to Tax Object Selling Value (NJOP) data, Land Ownership Area, Respondents' Livelihoods and Land Compensation Value for the construction of MORR III. The sample selection was done purposevely with a sample of 60 recipients of land compensation. Data Analysis Techniques use 1) Regression Analysis, and 2) Multiple Regression Analysis. The results showed that (1) the Sales Va lue of Tax Objects or values that showed the average price obtained from a sale and purchase transaction that occurred naturally was positively correlated and significantly affected the value of land compensation determined by the appraisal. Each increased in the Tax Object Sales Value of Rp. 1,000 per $m 2$ will increase the price of compensation by Rp. 540 perm 2 . The variable area of land ownership owned by the community receiving land compensation in the construction of MORR III has no significant effect on the value of land compensa tion. An increase in the area of land ownership owned by the people affected by land acquisition for the construction of MORR III only increased the value of land compensation obtained by Rp. 5,840 per m2. Land market price variables or prices that indicated the market value of land were positively correlated and have a significant effect on the value of land compensation determined by the appraisal. Land market price increased of Rp. 1000 per $m 2$ increased the price of land compensation by Rp.1,137 per m2. (2) Variable sale value of tax object, area of land ownership, and land market price indicated $64.0 \%$ representation of variables that affected the value of land compensation and jointly have a positive effect on the value of land compensation received by the community land acquisition affected in the construction of MORR III. ${ }^{* p p r m}$ *

Keywords: tax objects sale value, land sale and purchase transaction, implementation of the construction of the Manado outer Ring Road III

\begin{abstract}
ABS TRAK
Penelitian ini bertujuan untuk 1) Menganalisis pengaruh secara masing-masing antara nilai jual objek pajak, luas kepemilikan tanah, dan harga pasar tanah terhadap nilai ganti rugi tanah pada pengadaan tanah pembangunan Manado outer Ring Road III (MORR III). 2) Menganalisis pengaruh secara bersama-sama antara nilai jual objek pajak, luas kepemilikan tanah, dan harga pasar tanah terhadap nilai ganti rugi tanah pada pengadaan tanah pembangunan MORR III. Penelitian ini dilaksanakan di lokasi pembangunan (MORR III). sejak bulan Februari sampai Oktober 2019. Penelitian ini menggunakan metode deskriptif kuantitatif. Data yang dikumpulkan adalah data primer dan data sekunder. Data primer diperoleh langsung melalui wawancara dengan informan kunci yaitu Panitia Pengadaan Tanah Pelaksanaan MORR III. Data sekunder diperoleh dari Badan Pertanahan Sulawesi Utara dan Badan Pusat Statistik. Data sekunder menyangkut data Nilai Jual Objek Pajak (NJOP), Luas Kepemilikan Tanah, Mata Pencaharian Responden dan Nilai Ganti Rugi Tanah untuk pembangunan MORR III. Pemilihan sampel dilakukan secara sengaja dengan jumlah sampel 60 orang penerima ganti rugi lahan. Teknik Analisis Data menggunakan 1) Analisis Regresi, dan 2) Analisis Regresi Berganda. Hasil penelitian menunjukkan bahwa (1) Nilai Jual Objek Pajak atau nilai yang menunjukkan harga rata-rata yang diperoleh dari transaksi jual beli yang terjadi secara wajar berkorelasi positif dan berpengaruh signifikan terhadap nilai ganti rugi tanah yang ditetapkan oleh appraisal. Setiap peningkatan Nilai Jual Objek Pajak sebesar Rp.1.000 per m2 akan meningkatkan harga ganti rugi sebesar Rp.540 per m2. Variabel luas kepemilikan tanah yang dimiliki masyarakat penerima ganti rugi tanah pada pembangunan MORR III tidak berpengaruh secara signifikan terhadap nilai ganti rugi tanah. Peningkatan luas kepemilikan tanah yang dimiliki masyarakat yang terkena pembebasan lahan untuk pembangunan MORR III hanya menambah nilai ganti rugi tanah yang diperoleh sebesar Rp. 5.840 per m2. Variabel harga pasar tanah atau harga yang menunjukkan nilai pasaran tanah berkorelasi positif dan berpengaruh signifikan terhadap nilai ganti rugi tanah yang ditetapkan oleh appraisal. Peningkatan harga pasar tanah sebesar Rp. 1000 per m2 meningkatkan harga ganti rugi lahan sebesar Rp.1.137 per m2. (2) Variabel nilai jual objek pajak, luas kepemilikan tanah, dan harga pasar tanah menunjukkan keterwakilan sebesar $64,0 \%$ variabel yan $\mathrm{g}$ berpengaruh terhadap nilai ganti rugi tanah dan secara bersama-sama berpengaruh secara positif terhadap nilai ganti rugi tanah yang diterima oleh masyarakat yang terdampak pembebasan tanah pada pembangunan MORR III. ${ }^{* p m^{*}}$
\end{abstract}

Kata kunci : nilai jual objek pajak, transaksi jual beli tanah, pelaksanaan pembangunan Manado outer Ring Road III 


\section{PENDAHULUAN}

\section{Latar Belakang \\ Pembangunan merupakan upaya} pemerintah dalam mewujudkan masyarakat yang adil, makmur dan sejahtera berdasarkan Pancasila dan Undang-Undang Dasar Negara Republik Indonesia Tahun 1945, untuk menjamin terselenggaranya pembangunan untuk kepentingan umum diperlukan tanah yang pengadaannya dilaksanakan dengan mengedepankan prinsip kemanusiaan, demokratis dan adil.

Tanah merupakan salah satu unsur terpenting dalam pelaksanaan pembangunan. Kebutuhan akan lahan atau tanah tidak bisa dielakan lagi keberadaannya karena tanah merupakan kebutuhan utama dalam pelaksanaan pembangunan. Sebelum pelaksanaan suatu pembangunan komponen tersebut harus tersedia agar pembangunan dapat diwujudkan, untuk itu dibentuklah suatu lembaga pengadaan tanah untuk pembangunan (Muliawan, 2016).

Pengaturan tentang tanah dan kekayaan alam sebagaimana yang tertuang dalam UndangUndang Dasar Negara 1945 Pasal 33 ayat 3 menyebutkan bumi, air dan kekayaan alam yang terkandung di dalamnya dikuasai oleh Negara dan dipergunakan untuk sebesar-besarnya kemakmuran rakyat, dimana hak menguasai Negara tersebut, memberi wewenang kepada negara, diantaranya untuk mengatur dan menyelenggarakan peruntukan, penggunaan, persediaan dan pemeliharaan bumi, air dan ruang angkasa.

Pengadaan tanah dalam pembangunan infrastruktur berupa jalan merupakan hal yang sangat penting di Indonesia. Hal ini berkaitan erat dengan penyiapan fasilitas pendukung kegiatan masyarakat dalam menggerakkan roda ekonomi dan sosial. Akses jalan yang tersedia dan menjangkau daerah pusat perekonomian semakin memudahkan masyarakat dalam upaya pemenuhan kebutuhan.

Manado Outer Ring Road (MORR) merupakan proyek pembangunan jalan melingkar di Kota Manado dari Winangun, Maumbi, BuhaBengkol, Tuminting, Jembatan Soekarno, Bahu, Malalayang dan Kalasey. Pembangunan Manado Outer Ringroad terbagi dalam tiga tahap, dimana Manado Outer Ring Road Satu dan Dua sudah dapat dimanfaatkan masyarakat karena pembangunan fisiknya sudah selesai. Sedangkan Manado Outer Ring Road Tiga masih dalam tahap pengadaan tanah. Pelaksanaan pengadaan tanah tidak lepas dari berbagai masalah dan kendala yang ditemui baik oleh Panitia Pengadaan Tanah, Pemerintah Provinsi, maupun Instansi yang diberi mandat dalam pengadaan tanah untuk pembangunan Manado Outer ring road.

Panjang MORR 3 sekitar 11 kilometer yang akan dibangun dari kalasey ke Winangun untuk dikoneksikan dengan MORR 1 belum juga sampai pada pembangunan fisik jalan. Kendala yang paling mendasar dari pengadaan tanah untuk pembangunan MORR 3 ini tidak lepas dari proses pembebasan lahan yang tersendat. Pengadaan tanah untuk kepentingan umum tentu harus memperhatikan hak keperdataan yang melekat pada subjek hak atas tanah sebagai pemilik tanah. Walaupun atas tanah tersebut juga melekat fungsi sosial tanah, dimana untuk kepentingan umum wajib memperhatikan kepentingan masyarakat secara umum.

Penentuan harga tanah bukan hanya ditentukan lewat interaksi antara permintaan dan penawaran saja, namun lebih ditentukan pada karakteristik tanah pada lokasi tertentu. Berdasarkan permintaan dan penawaran tersebut maka terjadi apa yang disebut harga pasar. Penentuan nilai ganti rugi tanah pada pelaksanaan pengadaan tanah ditentukan oleh penilai pertanahan atau perseorangan yang melakukan penilaian secara independen dan profesional serta memiliki izin praktik penilaian dari Menteri Keuangan dan telah mendapat lisesensi dari Badan Pertanahan Nasional untuk menghitung nilai atau harga objek pengadaan tanah (Muliawan 2016).

Hubungan antara faktor-faktor seperti Nilai jual Objek Pajak, luas pemilikan tanah, dan harga pasar tanah terhadap penentuan nilai ganti rugi dalam pelaksanaan pengadaan tanah menarik untuk dikaji. Pengaruh faktor-faktor tersebut akan menghasilkan sebuah kajian untuk melihat faktor apa saja yang berpengaruh secara positif terhadap penentuan nilai ganti rugi lahan dalam pelaksanaan pembangunan manado outer Ring Road (MORR III).

\section{Rumusan Masalah}

Secara garis besar, permasalahan yang akan diuraikan lebih lanjut adalah sebagai berikut :

1. Apakah Nilai Jual Objek Pajak, luas kepemilikan tanah, dan harga pasar tanah secara masing-masing berpengaruh terhadap nilai ganti rugi tanah milik masyarakat? 
2. Apakah Nilai Jual Objek Pajak, luas kepemilikan tanah, dan harga pasar tanah secara bersama-sama berpengaruh terhadap nilai ganti rugi tanah milik masyarakat?

\section{Tujuan penelitian}

Tujuan penelitian ini antara lain:

1. Menganalisis pengaruh secara masingmasing antara nilai jual objek pajak, luas kepemilikan tanah, dan harga pasar tanah terhadap nilai ganti rugi tanah pada pengadaan tanah pembangunan Manado outer Ring Road III.

2. Menganalisis pengaruh secara bersamasama antara nilai jual objek pajak, luas kepemilikan tanah, dan harga pasar tanah terhadap nilai ganti rugi tanah pada pengadaan tanah pembangunan Manado outer Ring Road III.

\section{Manfaat Penelitian}

1. Manfaat Akademik

a. Penelitian ini diharapkan dapat memberikan kontribusi ilmiah, pengetahuan dan pengalaman dalam mengkaji pengadaan tanah dalam pelaksanaan Manado Outer Ring Road III.

b. Penelitian ini diharapkan dapat menambah literatur bahan kajian penelitian terkait pengadaan tanah dalam pengembangan jalan bagi peneliti selanjutnya.

2. Manfaat Praktis

a. Sebagai gambaran untuk memecahkan masalah-masalah yang berhubungan ganti rugi pengadaan tanah untuk kepentingan umum.

b. Sebagai bahan masukan kepada Pemerintah maupun instansi terkait dalam pelaksanaan pengadaan tanah untuk kepentingan umum.

\section{METODE PENELITIAN}

\section{Tempat dan Waktu Penelitian}

Penelitian ini dilaksanakan di lokasi pembangunan Manado Outer Ringroad III. Pelaksanaan penelitian ini dimulai sejak bulan Februari sampai bulan Oktober 2019.

\section{Jenis dan Sumber Data}

Penelitian ini menggunakan metode deskriptif kuantitatif dengan mengumpulkan data sekunder untuk menganalisis pengaruh nilai jual objek pajak, luas kepemilikan tanah, dan mata pencaharian terhadap nilai ganti rugi tanah dalam pelaksanaan pengadaan tanah Manado outer Ring Road III kemudian diintepretasikan.

Data yang diperoleh bersumber dari data primer dan data sekunder. Data primer diperoleh langsung melalui wawancara dengan key person atau informan kunci yaitu Panitia Pengadaan Tanah Pelaksanaan Manado outer Ring Road III terkait proses dan mekanisme pelaksanaan pengadaan tanah, sedangkan data sekunder diperoleh melalui instansi atau lembaga-lembaga terkait seperi Badan Pertanahan Sulawesi Utara, Badan Pusat Statistik, dan instansi terkait lainnya.

\section{Metode Pengumpulan Data}

Teknik yang digunakan dalam pengumpulan data dilakukan melalui metode survei yaitu dengan mendatangi langsung ke sumber data, yakni instansi yang terkait langsung dengan kegiatan penelitian yang dilakukan. Peneliti mengambil setiap data sekunder terkait Nilai Jual Objek Pajak (NJOP), Luas Kepemilikan Tanah, Mata Pencaharian Responden dan Nilai Ganti Rugi Tanah untuk pembangunan Manado outer Ring Road III. Metode lainnya adalah dengan melakukan studi kepustakaan lewat buku, dokumen dan searching data melalui internet untuk memperoleh informasi terkait undangundang pengadaan tanah serta peraturan lainnya yang memiliki keterkaitan.

\section{Definisi Ope rasional dan Variabel Penelitian}

Pada penelitian ini, definisi operasional dimaksudkan untuk menjelaskan makna variabel yang diteliti, yaitu, Ganti Rugi pada Pengadaan Tanah jalan TOL Manado-Bitung Variabel penelitian tersebut secara operasional dapat didefinisikan sebagai berikut:

1. Variabel Independen (X)

a. Nilai Jual Objek Pajak (NJOP) (X1)

Nilai Jual Objek Pajak atau nilai nyata/sebenarnya dengan memperhatikan NJOP tahun berjalan. Nilai nyata/sebenarnya disebut juga sebagai nilai pasar tanah, dapat berpedoman pada variabel: lokasi dan letak tanah, status tanah, peruntukan tanah, kesesuaian penggunaan tanah dengan rencana tata 
ruang wilayah atau perencanaan ruang wilayah atau kota yang telah ada, sarana dan prasarana yang tersedia, dan faktor lainnya yang mempengaruhi harga tanah.

b. Luas Kepemilikan Lahan (X3)

Luas bidang tanah (satuan meter persegi), adalah acuan dalam menentukan besarnya BPHTB yang akan dikalikan dengan harga tanah.

c. Harga Pasar Tanah (X3)

Harga pasar merupakan harga yang dibebankan kepada pembeli yaitu harga yang selaras dengan biaya pemasaran termasuk pengembalian suatu laba normal pada pemasok.

d. Mata Pencaharian Responden (X4)

Mata pencaharian adalah pekerjaan yang menjadi pokok penghidupan, dalam penelitian ini dibedakan antara petani dan non petani.

2. Variabel dependen (Nilai Ganti Rugi Lahan) (Y) Nilai Ganti Rugi adalah nilai penggantian terhadap kerugian baik bersifat fisik dan atau non fisik akibat pengadaan tanah kepada pemilik tanah, bangunan, tanaman dan benda-benda lain yang berkaitan dengan tanah yang dapat memberikan kelangsungan hidup.

\section{Penentuan Sampel}

Teknik sampling yang digunakan adalah purposive sampling yaitu memilih data responden secara sengaja sesuai dengan kriteria penelitian. Kriteria yang dimaksud adalah responden yang terkena dampak pembebasan lahan pembangunan manado outer Ring Road III sesuai data yang ada pada Panitia Pengadaan Tanah Pelaksanaan Pembangunan Manado outer Ring Road III. Jumlah sampel dalam penelitian ini berjumlah 60 orang penerima ganti rugi lahan.

\section{Analisis Regresi}

\section{Teknik Analisis Data}

Penggunaan analisis regresi diterapkan untuk mengevaluasi faktor-faktor yang berpengaruh terhadap nilai ganti rugi lahan yang diterima responden. Sebagai variabel respon adalah nilai ganti rugi lahan, sedangkan sebagai faktor bebas yang diduga berpengaruh terhadap variabel respon adalah: nilai jual obyek pajak (NJOP) tanah, zona nilai tanah, dan luas pemilikan tanah. Untuk mengetahui besarnya pengaruh dari suatu variabel bebas (independent variable) terhadap variabel terikat (dependent variable) maka penelitian ini menggunakan model regresi linear berganda dengan metode kuadrat terkecil atau Ordinary Least Square (OLS). Analisis regresi adalah studi ketergantungan dari variabel dependen pada satu atau lebih variabel independen, dengan tujuan untuk mengestimasi dan/atau memprediksi rata-rata populasi dan nilai ratarata variabel dependen berdasarkan nilai variabel independen yang diketahui (Syalkahfi, 2016).

Variabel dependen yang dipengaruhi variabel independen dinyatakan dalam variabel:

Dimana :

$$
\mathrm{Y}=\boldsymbol{f}(\mathrm{X} 1, \mathrm{X} 2, \mathrm{X} 3)
$$

$\mathrm{Y}=$ Nilai ganti rugi tanah $(\mathrm{Rp} / \mathrm{m} 2)$

$\mathrm{X} 1=$ Nilai Jual Obyek Pajak (NJOP) tanah responden $(\mathrm{Rp} / \mathrm{m} 2)$

$\mathrm{X} 2=$ Luas pemilikan tanah responden $(\mathrm{m} 2)$

X3 = Harga pasar tanah $(\mathrm{Rp} / \mathrm{m} 2)$

X3 = Mata Pencaharian Responden $($ Petani $=1$ dan non petani $=0$ ).

Kemudian ditransformasikan kedalam model regresi liner sebagai berikut:

$$
\mathrm{Y}=\alpha+\beta 1(\mathrm{X} 1)+\beta 2(\mathrm{X} 2)+\beta 3(\mathrm{X} 3)+\varepsilon
$$

Keterangan:

$\mathrm{Y}=$ Nilai ganti rugi lahan $(\mathrm{Rp} / \mathrm{m} 2)$

$\alpha \quad=$ Konstanta

$\beta 1, \quad \beta 2, \quad \beta 3=$ Koefisien Regresi Variabel Independen (Nilai Jual Objek Pajak, Zona nilai tanah, dan luas kepemilikan lahan)

$\varepsilon=$ Error term Variabel pengganggu atau faktorfaktor di luar variabel yang tidak dimasukkan sebagai variabel model di atas (kesalahan residual)

Untuk menguji hipotesis penelitian menggunakan Uji Asumsi Klasik yang terdiri dari Uji Normalitas Data, Multikolinieritas dan Uji Autokorelasi. Selanjutnya analisis regresi berganda menggunakan uji Korelasi (R), uji R2, uji $\mathrm{F}$ (uji serentak) dan uji t (uji parsial), untuk mengetahui besaran pengaruh antara variabel bebas dengan variabel tidak bebas.

a. Uji Asumsi Klasik

Analisis uji prasyarat dalam penelitian ini menggunakan uji asumsi klasik sebagai salah satu syarat dalam menggunakan analisis korelasi dan regresi berganda. Adapun pengujiannya dapat dibagi dalam beberapa tahap pengujian yang dapat dilihat pada pengujian berikut: 
1. Uji Normalitas Data Pengujian normalitas data digunakan untuk melihat apakah dalam sebuah model regresi, variable bebas dan variable terikat atau keduanya memiliki distribusi normal atau tidak. Model regresi yang baik adalah distribusi data normal atau mendekati normal.

2. Uji Multikolinieritas

Uji ini bertujuan untuk menguji apakah dalam model regresi ditemukan adanya korelasi antara variabel independen. Berdasarkan aturan variance infaltion factor (VIF) dan tolerance, maka apabila VIF melebihi angka 10 atau tolerance kurang dari 0,10 maka dinyatakan terjadi gejala multikolinieritas. Sebaliknya apabila nilai VIF kurang dari 10 atau tolerance lebih dari 0,10 maka dinyatakan tidak terjadi multikolinieritas.

3. Uji Heteroskedasitas

Uji heteroskedastisitas bertujuan untuk menguji apakah dalam model regresi terjadi ketidaksamaan variansi dari residual satu pengamatan ke pengamatan lain (Imam Ghozali, 2013). Pengujian heteroskedasti-sitas dilakukan dengan menggunakan uji Glejser. Pada uji Glejser, nilai residual absolut diregresi dengan variabel independen. Jika variabel independen signifikan secara statistik mempengaruhi variabel dependen, maka terdapat indikasi terjadi Heteroskedasitas. Hasil probabilitas dikatakan signifikan jika nilai signifikansinya diatas tingkat kepercayaan $5 \%$.

b. Uji t (Uji Parsial), uji koefisien determinasi (R2) dan uji f (Uji Simultan)

1) Uji Statistik t

Uji ini digunakan untuk mengetahui apakah variabel independen secara sendiri-sendiri mempunyai pengaruh signifikan terhadap variabel dependen. Pengujian koefisien regresi parsial (uji-t) untuk mengetahui pengaruh variabel bebas secara parsial atau individu terhadap variabel terikat dengan asumsi variabel yang lain konstan. Pengujian ini dilakukan dengan melihat derajat signifikansi masingmasing variabel bebas.
Ho = jika variabel bebas tidak berpengaruh terhadap variabel terikat.

$\mathrm{Hi}=$ jika variabel bebas berpengaruh terhadap variabel tidak bebas.

Dasar pengambilan menurut Santoso

(2014) :

a) Jika probabilitas (signifikansi) $>0,05 \quad(\alpha)$ maka H0 diterima. Artinya salah satu variabel independen tidak mempengaruhi variabel dependen secara signifikan.

b) Jika probabilitas (signifikansi) $<0,05 \quad(\alpha)$ maka Ho ditolak dan Hi diterima. Artinya salah satu variabel independen mempengaruhi variabel dependen secara signifikan. Dengan tingkat signifikansi sebesar 5\% $(\alpha=0,05)$. Uji $\mathrm{t}$ digunakan untuk membuat keputusan apakah hipotesis terbukti atau tidak.

2) Analisi Koefisien Determinasi (R2)

Untuk mengetahui besarnya pengaruh variabel independen yaitu Indeks Nilai Jual Objek Pajak (X1), Luas Kepemilikan Tanah (X2), dan Harga Pasar Tanah (X3), terhadap variabel dependen dalam hal ini Nilai Ganti Rugi Tanah (Y) maka digunakan analisis koefisien determinasi (R2).

Koefisien determinasi (R2) yang kecil atau mendekati nol berarti kemampuan variabel-variabel independen dalam menjelaskan variasi variabel dependen amat terbatas. Nilai R2 yang mendekati satu berarti variabel-variabel independen memberikan hampir semua informasi yang dibutuhkan untuk memprediksi variabel-variabel dependen atau semakin tinggi kemampuan variabel bebas dalam menjelaskan varians variabel terikatnya.

3) Uji Statistik F

Uji signifikansi ini pada dasarnya dimasukkan untuk membuktikan secara statistik bahwa seluruh variabel independen berpengaruh secara bersamasama terhadap variabel dependen, untuk itu pengujian hipotesis yang digunakan adalah:

$\mathrm{H} 0: \beta 1, \beta 2=0$ semua variabel independen tidak mempengaruhi variabel dependen secara bersamasama .

$\mathrm{H} 1: \beta 1, \beta 2 \neq 0$ semua variabel independen mempengaruhi variabel dependen secara bersama-sama. 


\section{Pada tingkat signifikansi 5 persen dengan kriteria pengujian yang digunakan sebagai berikut :}

a) $\mathrm{H} 0$ diterima dan $\mathrm{H} 1$ ditolak jika probabilitas $\mathrm{F}$ hitung > tingkat signifikansi 0,05 maka H0 diterima, artinya variabel independen secara serentak atau bersama-sama tidak mempengaruhi variabel yang dijelaskan secara signifikan.

b) H0 ditolak dan H1 diterima jika probabilitas $\mathrm{F}$ hitung < tingkat signifikansi 0,05 maka H0 ditolak, artinya variabel independen secara serentak atau bersama-sama mempengaruhi variabel yang dijelaskan secara signifikan.

\section{HASIL DAN PEMBAHASAN}

\section{Gambaran Umum Lokasi Pene litian}

Koridor Perencanaan Basic Design Jalan Manado Outer Ring Road III berada pada wilayah administratif Provinsi Sulawesi Utara yaitu pada Kota Manado dan Kabupaten Minahasa. terbesar yang ada di Sulawesi Utara, yang memiliki luas wilayah $15.762 \mathrm{Ha}$, namun dengan adanya program reklamasi Pantai Teluk Manado, luas daratannya telah bertambah kurang lebih seluas $67 \mathrm{Ha}$. Secara administratif Kota Manado terbagi dalam 9 (Sembilan) wilayah kecamatan dan 87 (delapan puluh tujuh) kelurahan, dan berbatasan dengan Kecamatan Wori (Kabupaten Minahasa Utara) dan Teluk Manado Sebelah Utara, Kecamatan Dimembe (Kabupaten Minahasa Utara) Sebelah Timur, Kecamatan Pineleng (Kabupaten Minahasa) Sebelah Selatan, dan Teluk Manado/Laut Sulawesi Sebelah Barat. Secara geografis, Kota Manado terletak di antara: $10^{\circ} 30^{\prime}-10^{\circ} 40^{\prime}$ Lintang Utara (LU) dan $124^{\circ} 40^{\prime}$ - $126^{\circ} 50^{\prime}$ Bujur Timur (BT). Secara umum kondisi morfologis Kota Manado terbentuk karena karakteristik alam kota itu sendiri yang unik dan berbeda dari kebanyakan kota di Indonesia pada umumnya. Kota ini memiliki bentang alam dengan unsur trimatra yaitu pantai, daratan dan perbukitan, yang terbentang dengan jarak yang relative kecil $(<$ $1 \mathrm{~km})$ di antara ketiga matra tersebut.

Kabupaten Minahasa merupakan Kabupaten yang berbatasan dengan Kota Manado yang memiliki luas wilayah $1.029,82 \mathrm{~km} 2$. Secara administratif Kabupaten Minahasa terbagi ke dalam 25 wilayah kecamatan dan 270 kelurahan/desa. Kabupaten Minahasa, dan berbatasan dengan Laut Sulawesi, Kota
Manado dan Kota Tomohon Sebelah Utara, Laut Maluku, Kabupaten Minahasa Utara dan Kota Tomohon Sebelah Timur, Laut Maluku dan Kota Tomohon Sebelah Selatan dan Kabupaten Minahasa Selatan dan Kota Tomohon Sebelah Barat. Secara geografis, Kabupaten Minahasa terletak di antara: $01^{\circ} 01^{\prime} 00^{\prime}$ - $01^{\circ} 29^{\prime} 00^{\prime}$ " Lintang Utara (LU) dan $124^{\circ} 34^{\prime} 00^{\prime \prime}$ - $125^{\circ} 05^{\prime} 00^{\prime \prime}$ Bujur Timut (BT).

\section{Manado Outer Ring Road III}

Jalan Lingkar (Ring Road III) merupakan jalan alternatif dari Jalan Nasional untuk menuju pusat kota Manado yang terkoneksi dengan Jalan Lingkar (Ring Road I) dan Jalan Nasional AmurangManado. Rencana Jalan Lingkar (Ring Road III) merupakan jalur yang menghubungkan antara Kota Manado ke arah selatan yaitu ke arah Kota Tomohon. Kondisi eksisting ruas Jalan Lingkar (Ring Road III) sebagai alternatif belum mempunyai trase jalan. Berdasarkan tinjauan lapangan yang telah dilakukan, dapat disimpulkan bahwa kondisi terrain di sekitar titik awal trase aitu di Ring Road Manado pada umumnya curam. Kondisi ini berlanjut hingga di daerah Winangun. Sementara dimulai dari Batu Kota, kondisi terrain pada kondisi eksisting berada pada kondisi dataran rendah. Setelah melewati daerah Malalayang menuju Kalasey, terrain eksisting kembali berangsur-angsur berubah menjadi dataran rendah kembali sampai di tepi pantai Kalasey di Jalan Nasional (Dekat Tugu BOBOCA), perbatasan Miahasa-Kota Manado.

Rute Jalan Lingkar (Ring Road III) dimulai dari Jalan Nasional Ring Road I dan akan berakhir di daerah Kalasey (70 meter dari Patung BOBOCA / Perbatasan Kabupaten Minahasa dan Kota Manado, dengan panjang $\pm 11.00 \mathrm{~km}$. Dari STA 0+000 yang berada di Ring Road I Manado hingga STA 0+800 yang berada di wilayah Winangun, trase jalan Ring Road akan menuju pusat kota Manado sementara dari STA 0+800 hingga titik akhir, trase akan terus menuju Malalayang dan Kalasey. Trase diawali dari Ring Road Manado I, kemudian bergerak ke arah Selatan menuju wilayah Malalayang, melewati wilayah Batu Kota, Aer Terang, Malalayang dan berakhir di sekitar tugu/patung Boboca, Malalayang, kota Manado. Titik-titik penting trase dan wilayah di sekitar Simpang Susun.

Trase Jalan Lingkar (Ring Road III) yang memiliki panjang $\pm 11.00 \mathrm{~km}$ ini direncanakan memiliki 1 buah simpang susun, yaitu Simpang Susun Ring Road, di titik trase (STA 0+000), akan diletakkan Simpang Susun Ring Road I, dimana simpang susun ini akan mengakomodir pergerakan kendaraan dari arah Winangun dan Manado yang hendak masuk ke dalam ruas jalan Ring Road. Dari 
hasil diskusi dengan pihak terkait, maka pada Simpang Susun Ring Road akan diletakkan frontage untuk mengakomodir jalan non Ring Road yang berada sejajar dengan rencana Simpang Susun Ring Road. Trase Jalan Lingkar (Ring Road III) ini akan melewati ujung dari rencana Simpang Susun Ring Road / Winangun (Citra Land) yang berada di daerah Perumahan Citra Land, Kota Manado. Keberadaan rencana Simpang Susun ini tidak mempengaruhi desain trase yang ada, karena trase hanya melewati ujung dari Simpang Susun. Elevasi rencana jalan Ring Road pun sudah didesain melewati batas aman dari elevasi Simpang Susun Winangun. Ruas Jalan Lingkar (Ring Road III) direncanakan akan melewati beberapa alur dan sungai, serta Jalan Lokal, Jalan Provinsi, maupun Jalan Nasional. Untuk mengatasi hal tersebut, maka pada tiap-tiap perpotongan akan dibuat suatu penanganan yang berdasarkan pada kondisi eksisting yang ada. Pada ruas ini, direncanakan akan terdapat 7 (tujuh) buah perpotongan dengan jalan eksisting yang akan difasilitasi, baik dengan menggunakan overpass maupun underpass. Pada ruas ini akan terdapat 11 (sebelas) persilangan dengan alur maupun dengan sungai. Untuk emmfasilitasi persilangan ini, maka akan digunaakn 12 (dua belas) box culvert serta 2 (dua) buah jembatan. Sepanjang ruas Jalan Lingkar (Ring Road III) memiliki medan relative datar berombak sehingga desain alinemen vertical pada segmen Ring Road III ini relatif cukup landau dengan presentase kelandaian berada pada kisaran 0,5-3\% saja. Memasuki wilayah Batu Kota Aer Terang, trase rencana melewati terrain eksisting yang usdah cukup curam, sehingga pada wilayah ini presentase kelandaian kemudian berkisar antara 1,5$4 \%$ dimana dalam penggunaan kelandaian $4 \%$, panjang landainya dibatasi dengan nilai panjang landau maksimum sebesar $700 \mathrm{~m}$ dan diberikan bordes dengan kemiringan 0,5-1,5\% di antara kelandaian-kelandaian yang cukup curam (3-4\%).

Rencana jalan Ring Road III dikembangkan untuk mengakomodasi pergerakan antar wilayah antara Manado serta wilayah sekitarnya. Penghematan waktu perjalanan merupakan salah satu manfaat yang diperhitungkan dalam perencanaan dan pembangunan prasarana umum. Manfaat penghematan waktu tersebut didapatkan dengan adanya pengurangan waktu perjalanan yang dirasakan oleh seluruh pengguna jalan. Nilai manfaat penghematan waktu tersebut akan semakin besar apabila pada prasarana jalan eksisting terjadi hambatan perjalanan seperti kemacetan. Manfaat yang akan diperoleh adalah selisih waktu perjalanan pada eksisting dengan pada Jalan Ring Road. Selisih waktu ini diperhitungkan menjadi manfaat setelah dikalikan dengan nilai waktu pada wilayah studi. Pembangunan
Jalan Ring Road diharapkan akan terjadi perbaikan pada sistem jaringan transportasi dalam wilayah Provinsi Sulawesi Utara dengan penambahan jaringan jalan. Dampak langsung pembangunan Jalan Ring Road tersebut adalah pengurangan kepadatan lalu lintas pada sistem jaringan jalan di Sulawesi Utara. Adanya pengurangan waktu tempuh perjalanan dan pengurangan kemacetan dari Kota Manado dan sekitarnya, maka akan terjadi penghematan biaya perjalanan para pelaku perjalanan.

Perbandingan waktu tempuh perjalanan antara kondisi do nothing dan kondisi do something, direpresentasikan oleh perbandingan waktu tempuh antar zona studi (Cid) di kawasan pada pemodelan lalu lintas. Perhitungan kelayakan ekonomi didasarkan pada manfaat yang dirasakan oleh masyarakat secara umum, tidsak hanya terbatas pada penggunan jalan (manfaat langsung) tetapi juga pada masyarakat sekitar (manfaat tidak langsung) dengan adanya pembangunan jalan Ring Road. Manfaat langsung yang diperhitungkan adalah pengurangan BOK (Biaya Operasi Kendaraan) dan penghematan waktu akibat adanya jaringan jalan Ring Road. Kedua jenis manfaat ini diperhitungkan berdasarkan pada pengguna jalan Ring Road dan pengguna jalan arteri. BOK diperhitungkan berdasarkan kecepatan kendaraan per jenis kendaraan, dimana kecepatan optimal (60-80 $\mathrm{km} / \mathrm{j}$ ) merupakan kecepatan yang memberika nilai BOK paling rendah. Dasar perhitungan BOK ini adalah Road User Soct Model, Bina Marga, 2005.

Penghematan waktu diperhitungkan atas dasar penghematan waktu yang dirasakan oleh pengguna jalan (Rind Road dan arteri) dengan adanya jaringan jalan Ring Road. Penghematan waktu diperhitungkan berdasarkan penghematan jalan Ring Road. Penghematan waktu perhitungan berdasarkan penghematan waktu yang diperoleh yang dikuantifikasi dengan nnilai waktu per jenis kendaraan/jam. Penetapan nilai waktu di Provinsi Sulawesi Utara didasarkan pada besaran nilai waktu dari PT. Jasa Marga, 1996 dan JIUTR Northern Extension (PCI, 1989) dengan perbandingan nilai PDRB perkapita wilayah Jabodetabek dengan Sulawesi Utara.

\section{Hasil Pengujian Hipotesis Menggunakan Uji Asumsi Klasik}

Pengujian hipotesis dalam penelitian ini dilakukan setelah memenuhi persyaratan dan memperoleh penaksiran yang terbaik. Adapun uji yang dilakukan dalam penelitian ini adalah uji normalitas, multikolinearitas, dan heteroskedastisitas. Pengujian asumsi klasik ini menggunakan program Statistik Package for the Social Science 25 (SPSS 25).

\section{Uji Normalitas}

Kevalidan model regresi linear yang dibuat dalam suatu penelitian diketahui melalui uji asumsi klasik seperti, uji normalitas, uji autokorelasi, uji 
multikolinieritas, dan uji heteroskedastisitas. Uji normalitas merupakan suatu bentuk pengujian tentang ramalan distribusi data, tujuan uji ini adalah untuk mengetahui apakah data yang diambil adalah data yang terdistribusi normal. Pada penelitian ini digunakan metode Kolmogorov Smirnov, Konsep dasar dari uji normalitas Kolmogorov Smirnov adalah dengan membandingkan distribusi data (yang akan diuji normalitasnya) dengan distribusi normal baku. Distribusi normal baku adalah data yang telah ditransformasikan ke dalam bentuk Z-Score dan diasumsikan normal. Hasil pengujian yang dilakukan lewat uji normalitas dapat dilihat pada Tabel 1.

Tabel 1. HasilUji Normalitas data Menggunakan Metode Kolmogorov Smirnov dengan SPSS 25.

\begin{tabular}{lllll}
\hline \multicolumn{5}{c}{ Kolmogorov Smirnov dengan SPSS } \\
\hline & statistic & sig & kriteria & Kesimpulan \\
\hline Unstandardized & 0,069 & 0,200 & $>0,05$ & Data berdistribusi normal \\
Residual & & & & \\
\hline Hasil Olahan, 2019 & & & & \\
\hline
\end{tabular}

Tabel 1 menunjukkan bahwa hasil uji normalitas dengan menggunakan metode Kolmogorov Smirnov didapatkan hasil signifikan dari uji normalitas sebesar 0,200 dimana hasil tersebut lebih besar dari taraf signifikansi 0,05, sehingga dapat disimpulkan bahwa data pada penelitian ini terdistribusi normal. Normalitas data juga dapat ditunjukan dengan Normal Q-Q Plot of Unstandardized Residual sebagaimana disajikan pada gambar 1. Hasil tambahan tersebut bukan berarti tidak dapat digunakan, tambahan ini juga sangat berguna untuk membuktikan bahwa data yang kita dapat berdistribusi normal.

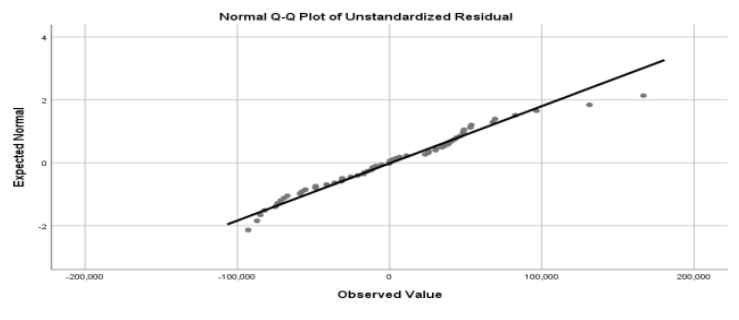

Gambar 1. Normal Q-Q Plot of Unstandardized Residual Hasil Olahan,

Garis diagonal dalam grafik (gambar 1) menggambarkan keadaan ideal dari data yang mengikuti distribusi normal. Titik-titik di sekitar garis adalah keadaan data yang kita uji. Jika kebanyakan titik-titik berada sangat dekat dengan garis atau bahkan menempel pada garis, maka dapat kita simpulkan jika data kita mengikuti distribusi normal. Namun jika ada satu saja titik yang berada jauh atau diluar garis Q-Q Plots maka menandakan ada data yang tidak terdistribusi dengan normal.

\section{Uji Multikolinieritas}

Uji multikolinieritas digunakan untuk melihat ada tidaknya korelasi yang tinggi antara variabel-variabel bebas dalam satu model regresi linear berganda. Jika terjadi korelasi yang tinggi di antara variabel-variabel bebasnya maka hubungan antara variabel bebas terhadap variabel respon menjadi terganggu. Multikolinieritas dilihat dengan nilai tolerance dan Variance Inflation Factor (VIF) dari masing-masing variabel bebas. Multikolinearitas terjadi jika nilai tolerance $<0,1$ yang tidak kurang dari 0,1 dan nilai VIF lebih dari 10. Nilai tolerance dan VIF masing-masing variabel bebas disajikan pada Tabel 2 .

Tabel 2. Hasil Uji Multikolinieritas dengan SPSS 25

\begin{tabular}{lccc}
\hline \multicolumn{1}{c}{ Variabel Bebas } & Tolerance & VIF & Multikolinieritas \\
\hline Nilai Jual Objek Pajak (X1) & 0,999 & 1,001 & Tidak Terjadi \\
Luas Tanah (X2) & 0,851 & 1,175 & Tidak Terjadi \\
Harga Pasar Tanah & 0,846 & 1,183 & Tidak Terjadi \\
Mata Pencaharian (X3) & 0,971 & 1,030 & Tidak Terjadi \\
\hline Hasil Olahan, 2019. & & &
\end{tabular}

Tabel 2 menunjukkan bahwa nilai tolerance dan multikolinieritas dari masing-masing variabel bebas terlihat nilai tolerance lebih besar dari 0,1 , demikian juga dengan nilai variance inflation factor lebih rendah dari 10, dengan demikian dapat disimpulkan bahwa pada model regresi yang dibuat tidak terjadi multikolinieritas di antara variabelvariabel bebas.

\section{Uji Heterokedastisitas}

Uji heteroskedastisitas dilakukan untuk melihat apakah terdapat ketidaksamaan ragam dari residual satu pengamatan ke pengamatan lainnya. Pengertian heteroskedatisitas adalah apabila kesalahan atau residual yang diamati tidak memiliki varian yang konstan. Kondisi heteroskedastisitas sering terjadi pada data cross section, atau data yang diambil dari beberapa responden pada suatu waktu tertentu. Model regresi yang memenuhi persyaratan adalah dimana terdapat kesamaan ragam dari residual satu pengamatan ke pengamatan yang lain tetap atau disebut homoskedastisitas. Pada penelitian ini uji heteroskedastisitas dilakukan dengan menggunakan Uji Glesjer. Ada tidaknya heteroskedastisitas dapat dilihat pada hasil ANOVA antara absolut (error) dengan semua variabel bebas dapat dilihat pada Tabel 3 .

Tabel 3. Hasil Uji Heterokedastisitas dengan SPSS 25

\begin{tabular}{lccccc}
\hline Model & $\begin{array}{c}\text { Sum of } \\
\text { Squares }\end{array}$ & df & $\begin{array}{c}\text { Mean } \\
\text { Squares }\end{array}$ & F & Sig. \\
\hline Regression & 0.30 & 3 & 0.010 & 0.960 & $0,418 \mathrm{~b}$ \\
Residual & 0.577 & 56 & 0.010 & & \\
\hline Total & 0.607 & 59 & & & \\
\hline Hasil Olahan, 2019 & & & &
\end{tabular}

Hasil Olahan, 2019. 
Tabel 3 menunjukkan bahwa ANOVA uji heteroskedastisitas diperoleh nilai signifikansi 0,418 atau lebih besar dari 0,05. Hal ini menunjukkan bahwa pada model regresi yang dihasilkan tidak terjadi heteroskedastisitas.

4. Koefisien deteminasi (Adjusted R-Square) dan Uji F (Uji Simultan)

Besarnya pengaruh variabel respon dapat dijelaskan oleh variabel bebas pada regresi linear berganda, yaitu pada nilai koefisien determinasi yang sudah disesuaikan (Adjusted $R$-Square). Dari hasil uji regresi diperoleh nilai Adjusted $R$-Square sebesar 0,640 yang menunjukkan bahwa variabelvariabel bebas tersebut dapat menerangkan keragaman variabel respon (nilai ganti rugi lahan) dengan kontribusi sebesar 64,0 persen, sedangkan 36,0 persen diterangkan oleh variabel lain yang tidak digunakan dalam penelitian ini.

Ketepatan fungsi regresi dalam menaksir nilai aktual dapat diukur dari Goodness of Fit. Secara statistik, setidaknya ini dapat diukur dari nilai koefisien determinasi dan nilai statistik F. Uji F bertujuan untuk mengetahui mengetahui apakah terdapat pengaruh antara variabel Nilai Jual Objek Pajak (NJOP), Luas Kepemilikan Lahan, Harga Pasar Tanah dan Mata Pencaharian secara bersamasama (simultan) terhadap variabel Ganti Rugi Lahan pembangunan Manado Outer Ring Road III, dilakukan Uji F (Uji Simultan). Untuk lebih jelasnya hasil perhitungan dapat dilihat pada Tabel 4.

\begin{tabular}{lccccc}
\multicolumn{6}{c}{ Tabel 4. Hasil Uji F (Uji Simultan) Menggunakan SPSS 25.} \\
\hline \multicolumn{1}{c}{ Model } & $\begin{array}{l}\text { Sum of } \\
\text { Squares }\end{array}$ & df & $\begin{array}{l}\text { Mean } \\
\text { Square }\end{array}$ & F & Sig. \\
& \multicolumn{5}{c}{ Squar } \\
\hline Regression & $4.588 \mathrm{E}+11$ & 3 & $1.529 \mathrm{E}+11$ & 31.845 & $0.000^{\circ}$ \\
Residual & $2.689 \mathrm{E}+11$ & 56 & 4802271508 & & \\
\hline Total & $7.277 \mathrm{E}+11$ & 59 & & & \\
\hline Hasil Olahan, 2019 & & & &
\end{tabular}

Berdasarkan

hasil

perhitungan menggunakan spss versi 25 diketahui bahwa nilai signifikansi untuk pengaruh Nilai Jual Objek Pajak (X1), Luas Kepemilikan Lahan (X2), dan Harga Pasar Tanah (X3) secara simultan terhadap Nilai Ganti Rugi Lahan (Y) adalah sebesar 0,000 atau lebih kecil dari pada $0,05(0,000<0,05)$ dan nilai $F$ hitung 31,845 lebih besar dari pada $\mathrm{F}$ tabel $(31,845>2,77)$ sehingga dapat disimpulkan bahwa NJOP, luas kepemilikan Tanah, harga pasar tanah dan mata pencaharian responden secara simultan berpengaruh positif dan signifikan terhadap nilai ganti rugi lahan. Maka pengujian hipotesis (secara bersama-sama, NJOP, luas kepemilikan lahan, dan mata pencaharian responden berpengaruh secara positif dan signifikan terhadap nilai ganti rugi tanah), diterima.

\section{Uji T (Uji Parsial)}

Penelitian ini memiliki 3 (tiga) hipotesis yang diuji untuk melihat apakah terdapat pengaruh antara Nilai Jual Objek Pajak (X1) dalam Rp/ $\mathrm{m}^{2}$, luas kepemilikan tanah (X2) dalam $\mathrm{m}^{2}$, dan harga pasar tanah (X3) dalam $\mathrm{Rp} / \mathrm{m}^{2}$ terhadap nilai jual tanah pembangunan Manado Outer Ring Road III yaitu dalam $\mathrm{Rp} / \mathrm{m}^{2}$.

Tabel 5. Hasil Uji T(Uji Parsial) menggunakan SPSS 25.

\begin{tabular}{lrrr}
\hline \multicolumn{1}{c}{ Variable bebas } & \multicolumn{1}{c}{ b } & t-hitung & Sig. \\
\hline Intersep & 37763.195 & -0.764 & 0.448 \\
NJOP Tanah $\left(\mathrm{X}_{1}\right)$ & 0.540 & 1.986 & 0.052 \\
Luas Kepemilikan Tanah $\left(\mathrm{X}_{2}\right)$ & 5.840 & 0.867 & 0.390 \\
Harga Pasar tanah $\left(\mathrm{X}_{3}\right)$ & 1.137 & 9.323 & 0.000 \\
\hline Hasil Olahan 2019 & & &
\end{tabular}

Hasil Olahan, 2019

a. Hasil Pengujian Hipotesis 1

Berdasarkan hasil perhitungan dengan menggunakan program SPSS 25 seperti terlihat pada Tabel 4 variabel Nilai Jual Objek Pajak (NJOP) memiliki t hitung sebesar 1,986 dan nilai signifikan sebesar 0,052 . Ketentuan pengambilan keputusan hipotesis diterima atau ditolak didasarkan pada besarnya nilai signifikansi. Jika signifikansi lebih kecil atau sama dengan $0,05(<0,05)$ dan t hitung lebih besar dari t tabel $(>2,00324)$ maka hipotesis diterima. Hasil penelitian diperoleh nilai signifikansi sebesar 0,052 atau lebih besar dari $0,05(0,052>0,05)$ dan $t$ hitung lebih kecil dari $\mathrm{t}$ tabel $(1,986<2,00324)$ maka disimpulkan bahwa pengujian hipotesis 1 (NJOP berpengaruh positif dan signifikan terhadap nilai ganti rugi lahan), ditolak.

b. Hasil Pengujian Hipotesis 2

Variabel luas kepemilikan tanah memiliki $\mathrm{t}$ hitung sebesar 0,867 dan nilai signifikansi sebesar 0,390 pada tingkat signifikansi 0,05. Dapat disimpulkan bahwa sig 0,390 lebih besar dari pada 0,05 $(0,390>0,05)$ dan $t$ hitung 0,867 lebih kecil dari t tabel $(0,867<2,00404)$ maka pengujian hipotesis 2 (Luas kepemilikan tanah berpengaruh secara positif dan signifikan terhadap nilai ganti rugi lahan), ditolak.

c. Hasil Pengujian Hipotesis 3

Berdasarkan hasil perhitungan dengan menggunakan program SPSS 25, variabel Harga Pasar Tanah memiliki t hitung sebesar 9,323 dan nilai signifikan sebesar 0.000 . Ketentuan pengambilan keputusan hipotesis diterima didasarkan pada besarnya nilai signifikansi, Jika signifikansi lebih kecil atau sama dengan 0,05 dan $\mathrm{t}$ hitung lebih besar 
dari t tabel $(2,00404)$ maka hipotesis diterima. Hasil penelitian diperoleh nilai signifikansi sebesar 0,000 atau lebih kecil dari 0,05 $(0,000<0,05)$ dan $t$ value sebesar 9,323 atau lebih besar dari $\mathrm{f}$ tabel $(9,323>2,00404)$ maka disimpulkan bahwa pengujian hipotesis 3 (harga pasar tanah berpengaruh positif dan signifikan terhadap nilai ganti rugi lahan), diterima.

\section{Pembahasan}

Setiap kegiatan pembangunan baik untuk kepentingan umum akan menyebabkan dampak terhadap lingkungan hidup dan kehidupan masyarakat. Dampak ini dapat bersifat positif dapat juga negatif. Salah satu jenis kegiatan pembangunan untuk kepentingan umum yang dikaji dalam penelitian ini adalah pembangunan jalur Manado outer Ring Road III. Pembangunan jalur Manado outer Ring Road III merupakan salah satu bagian dari kerangka kebijakan pembangunan yang dibuat oleh Pemerintah Provinsi Sulawesi Utara. Pembangunan Manado outer Ring Road III ditujukan untuk memberikan manfaat bagi masyarakat dalam hal penyediaan akses jalan alternatif untuk menuju pusat kota manado yang terkoneksi dengan jalan lingkar Ring Road I. Pembangunan Manado outer Ring Road III selain memberikan manfaat untuk penghematan waktu tempuh, juga akan memberikan kesempatan terbukannya aktivitas perekonomian seperti pembangunan perumahan dan permukiman, pembangunan ruko-ruko, tempat makan, dan pembangunan bangunan usaha lainnya seperti halnya yang terjadi di sepanjang jalur Ring Road I.

Berdasarkan pengumuman penetapan lokasi proyek pembangunan Manado outer Ring Road III Pemerintah meminta instasi yang berwenang dengan pertanahan (BPN) untuk memproses pembebasan tanah. Sesuai permintaan yang dimaksud, BPN menugaskan lembaga penilai atau apraisal independen untuk melakukan inventarisasi lahan serta memprakirakan besarnya harga ganti rugi lahan. Inventarisasi ini akan memberikan informasi terkait pemilik lahan yang terkena pembebasan, luasan masing-masing lahan dan prakiraan besarnya harga tanah. Berbekal hasil inventarisasi tersebut, BPN akan mengundang pemilik lahan dan ditambah instansi terkait di desa sampai Kabupaten untuk negosiasi harga tanah, dan mendiskusikan bentuk dan mekanisme ganti rugi. Jika negosiasi berhasil, maka akan dikeluarkan surat kesepakatan harga dan bentuk ganti rugi. Masyarakat pemilik lahan yang tidak setuju dari penetapan harga dan bentuk ganti rugi dapat menggugat ke Pengadilan Negeri. Jika tidak ada protes dari pemilik lahan, maka dilakukan proses pembebasan lahan oleh BPN. Setelah pembebasan lahan selesai dilakukan, BPN akan menyerahkan lahan tersebut berikut legalitas peralihan hak lahan tersebut untuk dilakukan pembangunan proyek sesuai dengan kegiatan yang direncanakan. Nilai ganti rugi yang diterima oleh masyarakat penerima ganti rugi disajikan pada Tabel 6, dan untuk menjaga privasi dari masyarakat penerima ganti rugi, peneliti menggati nama keluarga yang bersangkutan dengan kode berupa angka 1 sampai 60 sesuai dengan banyaknya jumlah sampel.

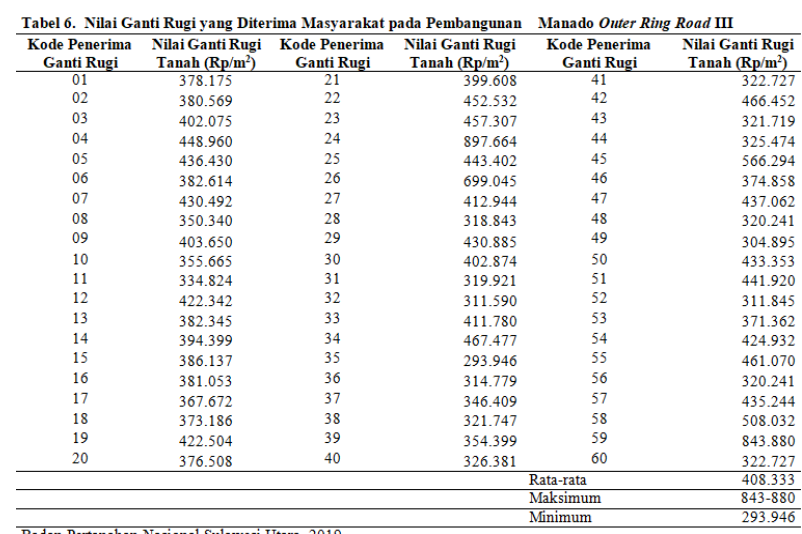

Tabel 6 menunjukkan bahwa semua responden yang terkena pembebasan mendapat-kan uang ganti rugi dengan nilai yang telah disepakati antara pemilik lahan dan panitia pembebasan lahan. Rata-rata nilai ganti rugi yang diperoleh adalah $\mathrm{Rp}$. 384.805 per m2, dengan nilai terendah Rp.293.946 per $\mathrm{m} 2$ dan tertinggi Rp.566.992 per m2. Adapun rincian nilai harga ganti rugi lahan dan Nilai Jual Objek Pajak yang diterima masyarakat disajikan pada Tabel 7.

Tabel 7. Perbandingan Nilai Ganti Rugi yang diterima Masyarakat dengan Nilai Jual Objek Pajak Tanah Masyarakat

\begin{tabular}{lrr}
\hline Nilai & $\begin{array}{r}\text { Harga Ganti Rugi } \\
\text { Tanah }\left(\mathrm{Rp} / \mathrm{m}^{2}\right)\end{array}$ & $\begin{array}{r}\text { Nilai Jual Objek Pajak } \\
\text { Tanah }\left(\mathrm{Rp} / \mathrm{m}^{2}\right)\end{array}$ \\
\hline Rata-rata & 408.333 & 54.450 \\
Maksimum & $843-880$ & 128.000 \\
Minimum & 293.946 & 14.000 \\
\hline
\end{tabular}

Badan Pertanahan Nasional Sulawesi Utara, 2019 (diolah).

Nilai harga ganti rugi lahan lebih tinggi dibanding NJOP tanah yang berlaku saat pembebasan lahan. Nilai ganti rugi yang diterima responden lebih tinggi dibanding NJOP, kisaran nilai harga ganti rugi dan NJOP tanah disajikan pada Tabel 7. Jauh sebelum dilakukan negoisasi lahan, Panitia Pembebasan Lahan telah melakukan survei harga pasar tanah yang dikumpulkan dari masyarakat sekitar maupun aparat pemerintahan desa, kelurahan dan kecamatan. 
Hasil pengolahan data menggunakan software SPSS versi 25 menunjukkan persamaan regresi linear berganda antara variabel Nilai Jual Objek Pajak (NJOP) (X1), variabel Luas Pemilikan Tanah (X2), variabel Harga Pasar Tanah (X3) Nilai Ganti Rugi Tanah (Y) pembangunan Manado Outer Ringroad III sebagai berikut:

$Y=37763.195+0.540(X 1)+5.840(X 2)+1.137(X 3)$

Pada penelitian yang dilakukaan pada taraf kepercayaan 95\%, variabel Nilai Jual Objek Pajak (X1) berkorelasi positif dan berpengaruh signifikan terhadap nilai ganti rugi tanah $(\mathrm{Rp} / \mathrm{m} 2)$. Setiap peningkatan Nilai Jual Objek Pajak sebesar Rp.1.000 per $\mathrm{m} 2$ hanya meningkatkan harga ganti rugi sebesar Rp.540 per m2. Pada pelaksanaan penetapan nilai ganti rugi tanah pemerintah menggunakan pihak ketiga, yaitu perseorangan yang secara independen dan profesional telah mendapat izin praktik penilaian dari Menteri keuangan dan telah mendapat lisensi dari Badan Pertanahan Nasional untuk menghitung nilai atau harga Obyek Pengadaan Tanah. Nilai Jual Objek Pajak menjadi dasar dalam penentuan nilai tanah, karena NJOP merupakan harga rata-rata yang diperoleh dari transaksi jual beli yang terjadi secara wajar. Pada penelitian ini NJOP berkorelasi secara positif dan berpengaruh secara signifikan terhadap pembentukan nilai ganti rugi tanah.

Variabel luas kepemilikan tanah yang diuji dalam penelitian ini tidak berpengaruh secara nyata atau signifikan terhadap nilai ganti rugi tanah meskipun hasilnya positif, hasil ini sesuai dengan teori dan penelitian yang dilakukan oleh Bjorklund dkk, (2006) dan Muchamad Imam Bintoro, (2014); bahwa luas tanah tidsak berpengaruh nyata dan signifikan terhadap nilai tanah per meter persegi yang akan di jual. Penjualan tanah dalam luasan yang besar cenderung sangat dipengerahui oleh kemampuan masyarakat sekitar, sehingga semakin besar luasan tanah yang ditawarkan untuk dijual akan berdampak semakin rendahnya harga tanah per meter perseginya. Selain itu, tanah yang memiliki luas tanah yang besar berdampak pada liquiditas tanah tersebut yang rendah. Peningkatan luas kepemilikan tanah yang dimiliki masyarakat yang terkena pembebasan lahan untuk pembangunan Manado outer Ring Road III hanya menambah perolehan nilai ganti rugi tanah sebesar $\mathrm{Rp} 5.840$ per $\mathrm{m}^{2}$. Luas lahan yang dimiliki oleh penerima ganti rugi mencerminkan seberapa besar kapasitas lahan tersebut akan digunakan, misalnya dalam hal ukuran rumah yang akan dibangun atau potensi banyaknya tanaman yang akan ditanam pada lahan tersebut untuk kegiatan produksi jika lahan tersebut merupakan lahan pertanian.
Variabel harga pasar tanah yang diuji dalam penelitian ini berkorelasi positif dan berpengaruh secara nyata atau signifikan terhadap harga ganti rugi lahan. Peningkatan harga pasar tanah sebesar Rp. 1000 per $\mathrm{m}^{2}$ meningkatkan harga ganti rugi lahan sebesar Rp.1.137 per $\mathrm{m}^{2}$. Harga pasar tanah selalu lebih tinggi dibanding NJOP namun peningkatannya tidak selalu memiliki trend yang sama. Perolehan Data harga pasar tanah cenderung subyektif, tidak ada angka pasti yang dapat dijadikan rujukan, tetapi biasanya apraisal mengambil nilai tertinggi berdasarkan kisaran yang ada. Sebelum melakukan pembebasan lahan, Panitia Pembebasan Lahan melakukan survei terkait harga pasar, dari hasil survei tersebut diperoleh kisaran harga terendah dan tertinggi. Harga pasar tanah ditentukan antara lain oleh kesuburan lahan, jarak lahan ke tempat-tempat strategis seperti pasar, kota dan lain-lain. Pada pembebasan lahan Pembangunan Manado outer ring road III apraisal juga mempertimbangkan harga bangunan dan harga tanaman yang terdapat pada suatu lahan.

Besarnya pengaruh variabel independen atau variabel bebas dapat dijelaskan oleh nilai koefisien determinasi yang sudah disesuaikan (Adjusted $R$-Square). Dari hasil pengujian regresi diperoleh nilai koefisien determinasi sebesar 64,0 persen yang menunjukkan bahwa variabel-variabel bebas tersebut dapat menerangkan keragaman variabel respon (nilai ganti rugi lahan) sebesar 64,0 persen, sedangkan 36,0 persen diterangkan oleh variabel lain yang tidak digunakan dalam penelitian ini. Variabel lain yang tidak diteliti dalam penelitian ini yaitu perhitungan atas nilai potensi tanah yang ada di setiap bidang tanah seperti nilai tanaman, bangunan dan potensi lain yang dimiliki tanah tersebut.

Pelaksanaan pengadaan tanah untuk pembangunan Manado outer Ring Road III berlokasi di dua Kabupaten atau Kota yaitu Kabupaten Minahasa dan Kota Manado. Pelaksanaan kegiatan pengadaan tanah yang dilakukan oleh panitia pengadaan tanah mengalami hambatan atau kendala pada saat proses pengadaan tanah berlangsung. Kendala yang dialami oleh panitia pengadaan tanah sama seperti kendala yang umum dihadapi setiap kali kegiatan pengadaan tanah berlangsung yaitu status tanah. Masalah status tanah yang dihadapi seperti sengketa waris antar keluarga, sengketa kepemilikan lahan, dan tanah yang ditelantarkan pemilik sehingga tidak jelas status tanah maupun status kepemilikannya. Masalah lain yang ditemui dalam pelaksanaan pengadaan tanah yaitu proses penetapan nilai ganti rugi oleh appraisal yang tidak 
disetujui oleh pemilik tanah terkait nilai ganti rugi yang diterima oleh masyarakat penerima ganti rugi, sehingga dalam penetapannya beberapa masyarakat menyampaikan protes dan menghambat proses administrasi dalam pelaksanaan pembebasan tanah untuk pembangunan Manado outer Ring Road III.

\section{KESIMPULAN DAN SARAN}

\section{Kesimpulan}

Berdasarkan hasil penelitian tentang pengaruh nilai jual objek pajak, luas kepemilikan tanah, dan mata pencaharian terhadap nilai ganti rugi tanah pada pembangunan Manado outer Ring Road III, peneliti mengambil kesimpulan sebagai berikut :

1. Variabel nilai jual objek pajak atau nilai yang menunjukkan harga rata-rata yang diperoleh dari transaksi jual beli yang terjadi secara wajar berkorelasi positif dan berpengaruh signifikan terhadap nilai ganti rugi tanah yang ditetapkan oleh Appraisal, sehingga hipotesis pertama yang ditetapkan peneliti pada penelitian ini diterima. Setiap peningkatan Nilai Jual Objek Pajak sebesar Rp.1.000 per m2 akan meningkatkan harga ganti rugi sebesar Rp.540 per m2. Variabel luas kepemilikan tanah yang dimiliki masyarakat penerima ganti rugi tanah pada pembangunan Manado outer Ring Road III tidak berpengaruh secara signifikan terhadap nilai ganti rugi tanah, sehingga hipotesis yang ditetapkan oleh peneliti pada penelitian ini ditolak. Peningkatan luas kepemilikan tanah yang dimiliki masyarakat yang terkena pembebasan lahan untuk pembangunan Manado outer ringroad III hanya menambah nilai ganti rugi tanah yang diperoleh sebesar Rp. 5.840 per $\mathrm{m} 2$. Variabel harga pasar tanah atau harga yang menunjukkan nilai pasaran tanah berkorelasi positif dan berpengaruh signifikan terhadap nilai ganti rugi tanah yang ditetapkan oleh appraisal, sehingga hipotesis keempat yang ditetapkan peneliti pada penelitian ini diterima. Peningkatan harga pasar tanah sebesar Rp. 1000 per $\mathrm{m} 2$ meningkatkan harga ganti rugi lahan sebesar Rp.1.137 per m2.

2. Variabel nilai jual objek pajak, luas kepemilikan tanah, dan harga pasar tanah menunjukkan keterwakilan sebesar $64,0 \%$ variabel yang berpengaruh terhadap nilai ganti rugi tanah dan secara bersama-sama berpengaruh secara positif terhadap nilai ganti rugi tanah yang diterima oleh masyarakat yang terdampak pembebasan tanah pada pembangunan Manado outer Ring Road III.

\section{Saran}

Berdasarkan hasil penelitian yang sudah dilakukan, terdapat beberapa saran peneliti yang disampaikan sebagai berikut :

1. Variabel Nilai Jual Objek dan Variabel luas kepemilikan tanah yang tidak berpengaruh secara signifikan dalam penentuan nilai ganti rugi yang diterima oleh pemilik tanah harus dikaji lewat penelitian lebih lanjut. Faktor sosial dan ekonomi dari masyarakat perlu mendapat pertimbangan yang baik dari pemerintah, dimana harus ada perhitungan loss of income atau penghasilan yang hilang bagi mereka yang hanya menggantungkan kehidupan dari hasil tanah yang diolah dan tidak memiliki pemasukan lain di luar pengusahaan tanah yang mereka miliki.

2. Harga Pasar Tanah yang berpengaruh secara positif dan signifikan terhadap penentuan nilai ganti rugi tanah harus menjadi acuan bagi Pemerintah lewat Appraisal atau penilai tanah juga Badan Pertanahan Nasional dalam kegiatan pembangunan lainnya. Pemerintah maupun masyarakat harus saling terbuka dalam proses penentuan harga pasar tanah agar pelaksanaan pembangunan serupa untuk kepentingan umum dijauhkan dari aspek komersialisasi.

\section{DAFTAR PUSTAKA}

Bintoro, M. I. (2014). Analisis Faktor-Faktor Yang Mempengaruhi Nilai Pasar Tanah Non Perumahan Di Kawasan Perkotaan Yogyakarta (Kpy) Kabupaten Sleman, Daerah Istimewa Yogyakarta (Doctoral dissertation, Universitas Gadjah Mada).

Bjorklund, Kicki, John Alex Dadzie, dan Mats Wilhelmsson, 2006, "Offer price, Dalam Pembangunan (Kajian Atas Peraturan Presiden Republik Indonesia.

Muliawan J. W. 2016. Cara Mudah Pahami Pengadaan Tanah Untuk Pembangunan Melalui Konsep 3 in 1 in the Land Acquistion. Buku Litera Yogyakarta.

Santoso, S. 2014. Statistik Multivariat, Edisi Revisi. Konsep dan Aplikasi dengan SPSS. PT. Elex Media Komputindo. Jakarta.

Syalkahfi, A. M. 2016. Analisis Pengaruh Pertumbuhan Ekonomi, Pengeluaran Pemerintah Sektor Pendidikan Dan Pengeluaran Pemerintah Sektor Kesehatan Terhadap Indeks Pembangunan Manusia Provinsi Lampung Tahun 1999 -2014. Jurnal, Vol 79. 